\section{Determine the prevalence of Brucella spp. and Leptospira spp. in blood samples by multiplex polymerase chain reaction collected from cattle, sheep and goats in herds located in provinces of Iran}

\author{
Faham Khamesipour,1 \\ Shahin Nejat Dehkordi, 2 \\ Taghi Taktaz Hafshejani,2 \\ Elahe Tajbakhsh, ${ }^{3}$ Shahrzad Azizi 4 \\ 1Young Researchers and Elite Club, \\ Shahrekord Branch, Islamic Azad \\ University, Shahrekord; \\ 2Department of Clinical Sciences, Faculty \\ of Veterinary Medicine, Shahrekord \\ Branch, Islamic Azad University, \\ Shahrekord; \\ 3Department of Microbiology, School of \\ Basic Sciences, Shahrekord Branch, \\ Islamic Azad University, Shahrekord; \\ 4Faculty of Veterinary Medicine, Shahid \\ Bahonar University of Kerman, Kerman, \\ Iran
}

\section{Abstract}

Leptospirosis and brucellosis are common zoonosis that affect many species of mammals mostly causing economical losses. Further, very important fact is huge danger for human and animal health around the world. The purpose of the study is to determine the prevalence of Brucella spp. and Leptospira spp. using multiplex polymerase chain reaction (mPCR) method, in blood samples collected from cattle, sheep and goats. In this study, a total number of 250 blood samples ( 5 cc of blood with ethilen diamin tetra asetic acid) were collected randomly from 100 cattle, 80 sheep and 70 goats located on 6 herds in Chaharmahal Va Bakhtiari and Esfahan provinces, Iran. After DNA extraction and setting of mPCR for Brucella spp. and Leptospira spp. mPCR products were screened. The DNA of these microorganisms was detected by multiplex PCR from 31 and 21 out of 100 cattle, respectively. Four of 70 goat's blood samples from goat breeding farms were positive for Leptospira spp. and 11 were positive for Brucella spp. Out of 80 sheep blood samples 23 were positive for Brucella spp. and 14 for Leptospira spp. The results of the present study show ruminant as an important reservoir for transmission of these zoonotic diseases to humans in Iran. mPCR has the ability to concurrently detect both Brucella and Leptospira species from blood samples of ruminants. The convenience and the possibility of detection of both bacteria at a time, strongly support the use of this MPCR for routine diagnostics.

\section{Introduction}

Zoonosis or diseases transmitted from animals to human have been recognized as significant public health concerns for period of one hundred years. Much of the primary history of veterinary science was focused on the control of diseases and many emerging and re-emerging infectious disease problems internationally are zoonotic. Leptospirosis and brucellosis are common zoonosis that affects many species of mammals, causing economical losses. Further, very important fact is huge danger for human and animal health (domestic and wild animals as well as humans) around the world. ${ }^{1}$

Brucellosis is caused by bacteria of the genus Brucella spp. It is a facultative intracellular gram-negative aerobic bacterium. Brucellosis is an important global infectious disease. It is characterized by reproductive failure in females and sterility in males. In males it causes a range of symptoms, characterized by undulating fever and it is one of the most ancient described zoonosis. ${ }^{2}$ It is particularly common in Middle East, South Europe and North Africa. ${ }^{3}$ Brucellosis is the most important infection of cattle causing abortion in Iran, as well. 4,5

Leptospirosis is a zoonosis of ubiquitous distribution, caused by infection of pathogenic motile spirochetes bacterium belonging to the genus Leptospira spp. They infect a range of hosts, involving mammals, reptiles, amphibians and birds. They pose an important public health problem of increasing concern and have a great impact on the reproductive efficiency of livestock. 6

The significance of these diseases is increased by many factors such as fast spreading, time-consuming treatment, difficulty of control and prevention and expensive therapy. These diseases cause dangerous consequences like prevention of trading animals and animal products; moreover these diseases inhibit public and economic development of breeders commonly found on pastoral regions. ${ }^{7}$ Both of these bacteria cause abortion in infected ruminants. Moreover, these infections are zoonotic and populations such as veterinary surgeons, farm workers, shepherds and abattoir workers are at high risk. Leptospira spp. and Brucella spp. may be excreted from affected animals in urine in large amount. This is a base of transmission between animals or from animal to human by a direct contact or through with urine contaminated food and water.8,9
Correspondence: Faham Khamesipour, Faculty of Veterinary Medicine, College of Veterinary Medicine, Islamic Azad University, Shahrekord Branch, Shahrekord, Iran.

Tel. +98.913 .4132858$

E-mail: Dr_Faham@yahoo.com

Key words: Brucella spp., Leptospira spp., Iran, multiplex polymerase chain reaction, ruminant, blood.

Acknowledgements: the authors would like to express their deep sense of gratitude and sincere thanks to Dr. Ismar Lutvikadic (Doctor of Veterinary Medicine at Veterinary Faculty, University of Sarajevo, Bosnia and Herzegovina) and Mr. Manouchehr Momeni Shahraki and the staff of the Biotechnology Research Center of Islamic Azad University of Shahrekord Branch in Iran.

Contributions: the authors contributed equally.

Received for publication: 12 February 2014

Revision received: 5 March 2014.

Accepted for publication: 12 March 2014.

This work is licensed under a Creative Commons Attribution NonCommercial 3.0 License (CC BYNC 3.0).

(C) Copyright F. Khamesipour et al., 2014

Licensee PAGEPress srl, Italy

Veterinary Science Development 2014; 4:5351

doi:10.4081/vsd.2014.5351

Nowadays, there are many laboratory techniques for diagnosis of leptospirosis and brucellosis in human and animals. Brucella spp. and Leptospira spp. can be serologically detected,10,11 nevertheless many factors may cause false positive and negative results and even cross reactions with other factors such as Salmonella spp., Yersinia spp. and E. coli. ${ }^{12-14}$ Bacteriological isolation is generally used for diagnosis. Though, the isolation of both pathogens, is usually time-consuming, difficult and laborious. ${ }^{15-18}$ Molecular diagnosis based on polymerase chain reaction (PCR) has been successfully described for the detection of Leptospira spp. and Brucella spp. ${ }^{19}$ To overcome these diagnostic problems molecular methods, for example PCR, have been used for increased specificity and sensitivity. Many PCRs have been developed for the detection of Brucella spp. and Leptospira spp. and it's practical to extract DNA from bacterial cells, tissue samples and blood.15,16,20-23

Multiplex PCR (m-PCR) is a precise PCR resulting procedure where multiple targets DNA sequences can be detected in a single reaction. ${ }^{24,25}$ Application of this assay to Brucella spp. and Leptospira spp. can easily detect these organisms at the same time from infected animals. mPCR diagnostics would 
help to overcome these difficulties and increase the diagnostic capacity of PCR. MPCR is cost effective and has the potential to save considerable amounts of time.

The purpose of this study is to determine the prevalence of Brucella spp. and Leptospira spp. in blood samples collected from cattle, sheep and goats in 6 herds located in Chaharmahal Va Bakhtiari and Esfahan provinces (Iran) using mPCR method. mPCR has the ability to concurrently detect both Brucella spp. and Leptospira spp. from blood samples of ruminants. Understanding of these diseases in the cattle and sheep populations is serious for both, the veterinary and public health services. Practical priorities must be set and controls must be implemented.

\section{Materials and Methods}

\section{Samples and DNA extraction}

For the purpose of testing, from February 2013 to March 2013, 250 blood samples (jugular vein sampling) were collected randomly from 100 cows, 80 sheep and 70 goats (more than 8 months of age) from 6 herds located in Chaharmahal Va Bakhtiari and Esfahan provinces (Iran). Five cc of blood with EDTA (ethilen diamin tetra asetic acid) was collected from jugular vein of each sheep, cattle and goat. All samples were sent under refrigeration to the Biotechnology Research Centre of Islamic Azad University of Shahrekord. It was stored at $-20^{\circ} \mathrm{C}$ until DNA extraction. DNA was extracted from blood samples by DNA extraction and purification kit (Cinnagen, Tehran, Iran) according to manufacturer's instructions. The extracted DNA was quantified by spectrophotometric measurement at a wavelength of $260 \mathrm{~nm}$ according to the method described by Sambrook and Russell. ${ }^{26}$

\section{Primers, DNA amplification and screening of polymerase chain reaction products}

In the study oligonucleotide primer sequences were applied, as described by Baily et al. ${ }^{15}$ and Theodoridis et al. ${ }^{27}$ before. These oligonucleotide primer sequences were formed in Table 1. The mPCR assay was performed in a last volume of $25 \mu \mathrm{L}$ mixture containing 50 mmol KCl, 10 mmol Tris- $\mathrm{HCl}(\mathrm{pH} 8.3), 1.5$ mmol $\mathrm{MgCl} 2,0.2 \mathrm{mmol}$ of each deoxynucleotide triphosphate, $0.5 \mu \mathrm{mol}$ of each primer, 1.25 unit Taq polymerase (Cinnagen, Tehran, Iran) and $5 \mu \mathrm{lL}$ of DNA template. The expected size of amplicons was 223 bp for Brucella spp. and 408 bp for Leptospira spp.; the mPCR assay established the novel primers of PCR assays.

Reactions were initiated at $94^{\circ} \mathrm{C}$ for $5 \mathrm{~min}$, followed by 30 cycles of $94^{\circ} \mathrm{C}$ for $1 \mathrm{~min}, 58^{\circ} \mathrm{C}$ for $1 \mathrm{~min}, 72^{\circ} \mathrm{C}$ for $1 \mathrm{~min}$ and a last elongation step at $72^{\circ} \mathrm{C}$ for $5 \mathrm{~min}$, with a last hold at $4^{\circ} \mathrm{C}$. The products obtained at the end of $\mathrm{MPCR}$ were run by $2 \%$ gel electrophoresis and stained with ethidium bromide (120 V/208 mA). Then the products were screened in UV screening systems. 100 bp molecular weight markers
(100 bp ladder, Fermentas GmbH, St. Leon-Rot, Germany) were used as standard measure.

\section{Statistical analysis}

Data were analyzed by using SPSS (version 15) software.

\section{Results}

In this study, DNA extractions from the collected samples were carried out and mPCR were applied for Brucella spp. and Leptospira spp., then mPCR products were screened. Results of these screenings were detection of Brucella spp. positive products observed in the fragments of 223 base pairs and Leptospira spp. positive products observed in the fragments of 408 base pairs (Figure 1).

The results of the prevalence of Brucella

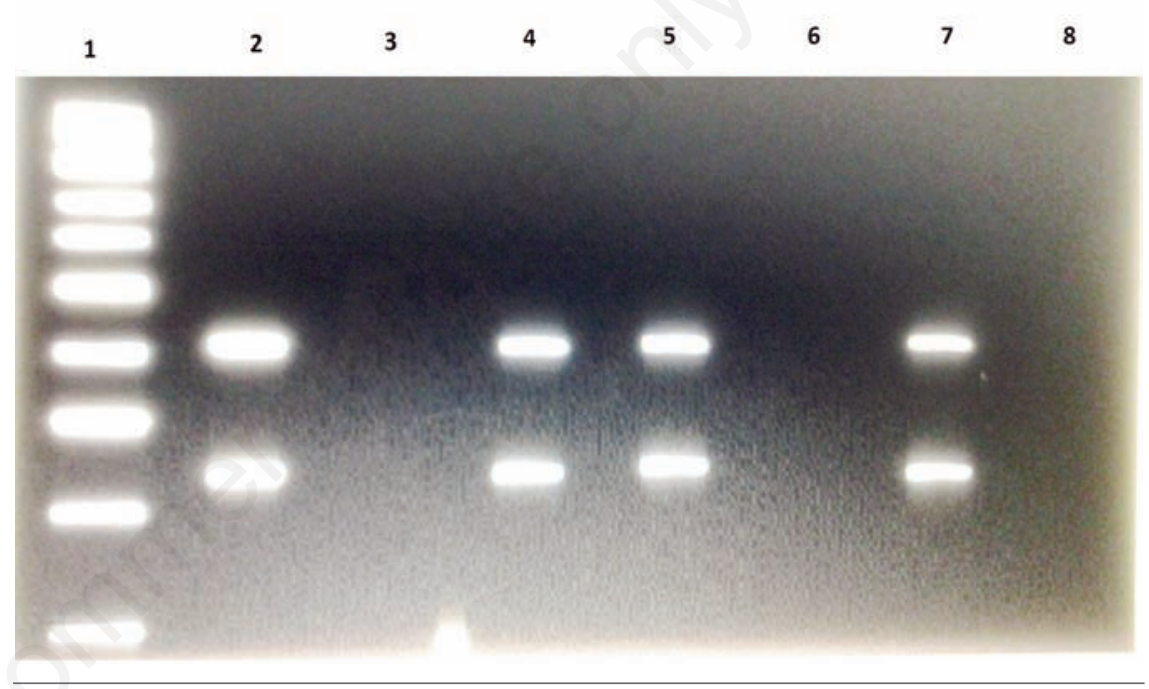

Figure 1. Ethidium bromide-stained agarose gel electrophoresis of Multiplex PCR for the detection of Brucella spp. and Leptospira spp. in samples after PCR amplification (PCR products of Brucella spp.: $223 \mathrm{bp}$, and PCR products of Leptospira spp.: $408 \mathrm{bp}$ ). Lane 1: 100 bp DNA ladder (Fermentas, Germany); Lanes 2: are positive control; Lanes 3: Negative control; Lanes 4, 5 and 7: positive samples; Lanes 6 and 8: negative samples.

Table 1. The oligonucleotide primers for Brucella spp. and Leptospira spp.

\begin{tabular}{llcc} 
Genus/species & Primer set $\left(\begin{array}{lll}5^{\prime} & 3^{\prime}\end{array}\right)$ & Target gene & Length of PCR product \\
Brucella spp. & TGGCTCGGTTGCCAATATCAA & BCSP31 & $223 \mathrm{bp}$ \\
& CGCGCTTCCTTCAAGGTCTG & & \\
Leptospira spp. & $\begin{array}{l}\text { GGCTATCTCCGTTCACTCTTTG } \\
\text { ATCGCCGACATTCTTTCTACACG }\end{array}$ & LipL41 & $408 \mathrm{bp}$ \\
\hline
\end{tabular}

Table 2. The results of the prevalence of Brucella spp. and Leptospira spp. in blood samples from cattle herds in Esfahan and Chaharmahal Va Bakhtiari province, Iran.

\begin{tabular}{|c|c|c|c|c|c|c|c|}
\hline \multirow[t]{2}{*}{ Province } & \multirow{2}{*}{$\begin{array}{l}\text { No. samples } \\
\text { Cattle }\end{array}$} & \multicolumn{2}{|c|}{ Sex $(\%)$} & \multicolumn{2}{|c|}{ Positive (\%) Brucella spp. } & \multicolumn{2}{|c|}{ Positive (\%) Leptospira spp. } \\
\hline & & Male & Female & Male & Female & Male & Female \\
\hline Esfahan & 66 & $4(6.07)$ & $62(93.93)$ & 0 & $9(14.51)$ & $1(25)$ & $6(9.67)$ \\
\hline Chaharmahal Va Bakhtiari & 34 & $2(5.89)$ & $32(94.11)$ & $1(50)$ & $21(65.62)$ & $1(50)$ & $13(40.62)$ \\
\hline Total & 100 & $6(6)$ & $94(94)$ & $1(50)$ & $30(31.91)$ & $2(33.33)$ & $19(20.21)$ \\
\hline
\end{tabular}


spp. and Leptospira spp. in cattle, sheep and goats blood samples are presented in Tables 24. The presence of Brucella spp. and Leptospira spp. DNA were detected by multiplex PCR from 31 and 21 out of 100 cattle, respectively. Four of 70 goat's blood samples from goat breeding farms were positive for Leptospira spp. and 11 were positive for Brucella spp. Out of 80 sheep blood samples 23 were positive for Brucella spp. and 14 for Leptospira spp.

The presence of Brucella and Leptospira species DNA were detected by multiplex PCR from $1(50 \%)$ and $2(33.33 \%)$ out of 6 male cattle, and their presence was 30 (31.91\%) and 19 (20.21\%) out of 94 female cattle, respectively. Also, multiplex PCR detect DNA of bothmicroorganisms from 4 (22.2\%) and 3 (16.66\%) out of 18 male sheep; and from 19 (30.64\%) and $11(17.74 \%)$ out of 62 female sheep.

Brucella and Leptospira species DNA was also detected from 4 (19.04\%) and 2 (14.28\%) out of 21 male goat, and from 7 (14.28\%) and 2 (6.25\%) out of 49 female goat, respectively.

Cattle has the highest incidence of Brucella spp. and Leptospira spp. diseases while, goats have the lowest. In comparison, Esfahan has lower incidence while Chaharmahal Va Bakhtiari has higher incidence of diseases caused by Brucella spp. and Leptospira spp.

\section{Discussion and Conclusions}

Brucellosis and leptospirosis are diseases of economic importance to any livestock enterprise since they cause abortions in infected animals. ${ }^{28,29}$

Brucella and Leptospira species infections usually occur after entering the infected animals to herds. Bacteria from different sources, including infected animals and even ingestion of contaminated food and water, can cause bac- teriemia. Target tissue for bacteria during pregnancy is placenta. Abortion occurs as a result of the infection. 5

Leptospira spp. and many species of Brucella are the main factors that cause abortion in the last 2 months of pregnancy in Iran. Leptospirosis has been diagnosed in Iran for many years by MAT and culture methods and the first use of PCR for detection of Leptospira spp. in Iran, goes back to 2007.30-32

Also, the first report of the isolation of $B$. abortus in Iran as the cause of abortion in cattle dates back to $1944 .{ }^{33}$ Since then, this organisms has been isolated on many occasions from bovine fetuses and cow's milk, ${ }^{4}$ and now the prevalence rate of brucellosis in sheep and goat is $340 / 10,000$ and in cattle is $56 / 10,000.34$

The diagnosis of brucellosis and leptospirosis is typically based on isolation from clinical specimens or serologic evidence of antibodies. The culturing takes days to weeks but has the advantage of detecting the organism directly. For rapid testing of clinical samples or for field surveys, immunological methods were used. However, antigen-antibody interactions can be complicated by nonspecific interactions and false positives from vaccinated animals with high levels of circulating antibodies and can be misdiagnosed as active infections. 5,18

PCR is a promising option for the diagnosis of various pathogens, and it is a potentially useful method for the detection of Brucella and Leptospira species from isolated bacteria, blood, semen or highly contaminated tissues. $15,16,18,23,35,36$

Different methods were used in past research. 37 Furthermore, the blood and milk samples obtained from cattle, cheese samples, human blood samples and the samples obtained from naturally infected cows were also used in the research. 7 There are also available studies evaluating the infection agents by PCR in cattle and in sheep with bru- cellosis cases that ended with abortion. 17

In Iran, several reports show that the high and low prevalence rate of leptospirosis and brucellosis in different provinces are similar to our study. Reports show that the high prevalence rate of leptospirosis in Iran including Tehran (24.6\%), ${ }^{38}$ Mashhad (24.24\%), ${ }^{39}$ Shiraz $(32 \%),{ }^{40}$ Karaj (46.8\%), ${ }^{41}$ Guilan $(22 \%),{ }^{42}$ Ahvaz (53.73\%), 43 and the earliest study on the prevalence of leptospirosis (L. interrogans) in Iran indicated a positive rate of $31 \%$ in cattle and $17 \%$ in sheep, ${ }^{44}$ but probably Leptospirosis in Iran is more prevalence than what it seems but since it identified has need to correct laboratory analysis.

Moshkelani et al. detected and reported Brucella spp. and Leptospira spp. by multiplex polymerase chain reaction (PCR) from aborted bovine, ovine and caprine fetuses in Iran. In total of the 276 specimens, 40 (14.4\%) and 25 (9.0\%) were identified as positive for Brucella spp. and Leptospira spp., respectively. ${ }^{5}$

According to reports of Parın et al. in Turkey, bands related with both Brucella spp. and Leptospira spp. were detected 24 (31.2\%) out of 77 mPCR positive samples. From the remaining 53 (68.8\%) samples, 33 samples (62.3\%) showed positive bands only related with Brucella spp. and 20 samples (37.7\%) showed positive bands only related with Leptospira spp. The main conclusion of this study was the use of multiplex PCR as a reliable, sensitive and fast technique. ${ }^{7}$

Cetinkaya et al. detected $80 \%$ sensitivity and $91 \%$ specificity in their research conducted by using primer sequences targeted to $16 \mathrm{~S}$ rRNA in which microbiological cultures obtained from gastric content of aborted lambs were used. ${ }^{17}$

In Turkey, the antibodies against $B$. abortus were detected in serum samples of aborted dairy cattle as $68.1,65.6,58.9$ and $55.2 \%$ by the Competitive Enzyme-Linked Immunosorbent

Table 3. The results of the prevalence of Brucella spp. and Leptospira spp. in blood samples from sheep herds in Esfahan and Chaharmahal Va Bakhtiari province, Iran.

\begin{tabular}{|c|c|c|c|c|c|c|c|}
\hline \multirow[t]{2}{*}{ Province } & \multirow{2}{*}{$\begin{array}{c}\text { No. samples } \\
\text { Sheep }\end{array}$} & \multicolumn{2}{|c|}{$\operatorname{Sex}(\%)$} & \multicolumn{2}{|c|}{ Positive (\%) Brucella spp. } & \multicolumn{2}{|c|}{ Positive (\%) Leptospira spp. } \\
\hline & & Male & Female & Male & Female & Male & Female \\
\hline Esfahan & 26 & $7(26.92)$ & $19(73.08)$ & $1(14.28)$ & $9(47.36)$ & $1(14.28)$ & $3(15.78)$ \\
\hline Chaharmahal Va Bakhtiari & 54 & $11(20.37)$ & $43(79.63)$ & $3(27.27)$ & $10(23.25)$ & $2(18.18)$ & $8(18.60)$ \\
\hline Total & 80 & $18(22.5)$ & $(77.5) 62$ & $4(22.22)$ & $19(30.64)$ & $3(16.66)$ & $11(17.74)$ \\
\hline
\end{tabular}

Table 4. The results of the prevalence of Brucella spp. and Leptospira spp. in blood samples from goat herds in Esfahan and Chaharmahal Va Bakhtiari province, Iran.

\begin{tabular}{|c|c|c|c|c|c|c|c|}
\hline \multirow[t]{2}{*}{ Province } & \multirow{2}{*}{$\begin{array}{l}\text { No. samples } \\
\text { Goat }\end{array}$} & \multicolumn{2}{|c|}{$\operatorname{Sex}(\%)$} & \multicolumn{2}{|c|}{ Positive (\%) Brucella spp. } & \multicolumn{2}{|c|}{ Positive (\%) Leptospira spp. } \\
\hline & & Male & Female & Male & Female & Male & Female \\
\hline Esfahan & 24 & $7(29.16)$ & $17(70.84)$ & $1(14.28)$ & 0 & 0 & 0 \\
\hline Chaharmahal Va Bakhtiari & 46 & $14(30.43)$ & $32(69.57)$ & $3(21.42)$ & $7(18.75)$ & $2(14.28)$ & $2(6.25)$ \\
\hline Total & 70 & $21(30)$ & $49(70)$ & $4(19.04)$ & $7(14.28$ & $2(14.28)$ & $2(6.25)$ \\
\hline
\end{tabular}


Assay (C-ELISA), Complement Fixation Test (CFT), Rosebengal Plate Test (RBPT) and Serum Agglutination Test (SAT), respectively. The total of $66(40.5 \%)$ of sera were positive for Leptospira antigen. ${ }^{3}$

Saad et al. reported that PCR method is more specific and sensitive than FAT (Florescense Antibody Test) and MAT (Microscopic Agglutination Test) for detection of Leptospira agents in semen, urine and sera of bulls. ${ }^{45}$ By evaluating the studies given above, it was evident that Brucella and Leptospira species were studied separately, and there was not any consideration of investigating these two bacteria together until the multiplex PCR study was conducted by Richtzenhain et al. In that study, it was reported that diagnosis of Brucella spp. and Leptospira spp. could be made in one tube by using $\mathrm{mPCR}$ and the sensitivity and specificity of this process was reported as $100 \%$ or 92 $93 \%$, respectively. It was also reported that the diagnosis of these two pathogens should be made more rapidly and more sensitive in routine laboratories. 18

PCR is applied for detection of various microorganisms, including clinical bacteria and viruses. Sensitivity of PCR is so high, that other methods such as isolation and culture of organisms could not compete with this method anymore. Therefore, this method is a suitable approach to find microorganisms in acute infections and in recent years the PCR technique has increasingly been used as a supplementary method for diagnosis of brucellosis and leptospirosis.6,37,46-48 By the guidance of these data given above, we decided to detect Brucella and Leptospira species in cattle, sheep and goats for our research. The goal of our study is presentation of molecular method as faster assay to get more sensitive results. It is also approved that multiplex PCR method is useful in optimal level, not PCR method based upon single locus sequence principle for detection of two bacteria species at the same time. By simultaneously amplifying more than one locus in the same reaction, mPCR has been identified as a rapid and convenient screening assay, with both clinical and research applications. The results show that developed mPCR assay was able to successfully detect Brucella spp. and Leptospira spp. This method is not a substitute for single PCR, but it can be used to cut the amount of required tests and deliver results more rapidly and cheaply.

The results of the present study showed that the ruminant can be an important reservoir for transmission of these zoonotic diseases to humans in Iran. With thanks to mPCR it is possible to concurrently detect both Brucella spp. and Leptospira spp. from blood samples of these animals. Several control programs should be performed in Iran on ruminants. The present study shows that molecular methods are right, reliable and rapid assays for detection and identification of Brucella spp. and Leptospira spp. in samples from ruminants. It seems that this study is the first report of direct detection and segregation of Brucella and Leptospira species by mPCR assays in ruminant blood samples in Iran. We hope that the mPCR method introduced in this study as a right, safe, fast, sensitive and specific assay for detection and segregation of Brucella spp. and Leptospira spp. in all samples will be of great benefit in the future.

\section{References}

1. Taylor LH, Latham SM, Woolhouse MEJ. Risk factors for human disease emergence. Philos Trans R Soc Lond B Biol Sci 2001;356:983-9.

2. Nicoletti P. A short history of brucellosis. Vet Microbiol 2002;90:5-9.

3. Genc 0, Otlu S, Sahin M. Seroprevalence of Brucellosis and Leptospirosis in aborted dairy cows. Turk J Vet Anim Sci 2005;29: 359-66.

4. Zowghi E, Ebadi A, Vandyousefi DJ. Investigations bactériologiquessur la brucellose bovine, ovine et caprine en Iran. Rev Sci Tech 1984;3:583-8.

5. Moshkelani S, Javaheri-Koupaei M, Rabiee S, Moazeni M. Detection of Brucella spp. and Leptospira spp. by multiplex polymerase chain reaction (PCR) from aborted bovine, ovine and caprine fetuses in Iran. Afr J Microbiol Res 2011;5: 4627-30.

6. Levett PN. Leptospirosis. Clin Microbiol Rev 2001;14:296-326.

7. Parin U, Kirkan S. The detection of Brucella sp. and Leptospira sp. in cattle by multiplex polymerase chain reaction (mPCR). Animal Health Prod Hyg 2012;1: 100- 5 .

8. Heinemann MB, Garcia JF, Nunes CM, et al. Detection and differentiation of Leptospira spp. serovars in bovine semen by polymerase chain reaction and restriction fragment length polymorphism. Vet Microbiol 2000;73:261-7.

9. Ocholi RA, Kwaya JKP, Ajogi I, Bale J00. Abortion due to Brucella in sheep in Nigeria. Rev Sci Tech 2005;24:973-9.

10. Naigowit $P, \quad$ Wangroongsarb $P$, Petkanchanapong W, et al. A comparative evaluation of different methods for the serological diagnosis of leptospirosis. $\mathrm{J}$ Trop Med Parasitol 2000;23:59-65.

11. Gall D, Nielsen K. Serological diagnosis of bovine brucellosis: a review of test performance and cost comparison. Rev Sci Tech 2004;23 989-1002.

12. Kittelberger R, Hilbink F, Hansen MF, et al.
Serological cross reactivity between Brucellaabortus and Yersinia enterolitica $0: 9$ the use of Yersinia outer membrane protein for specific detection of Yersinia enterocolitica infections in ruminants. Vet Microbiol 1995;57:361-71.

13. Gallien P, Dorn C, Alban G, et al. Detection of Brucella species in organs of naturally infected cattle by polymerase chain reaction. Vet Rec 1998;142:512-4.

14. Bolin CA. Diagnosis and control of bovine leptospirosis. Proceedings of the 6th Western Dairy Management Conference, 2003, Reno, NV, USA. pp. 155-60. Available from: http://www.wdmc. org/2003/ Diagnosis\%20and\%20Control\%20of\%20Bo vine\%20Leptospirosis.pdf

15. Baily GG, Krahn JB, Drasar BS, Stoker NG. Detection of Brucella melitensis and Brucella abortus by DNA amplification. J Trop Med Hyg 1992;95:271-5.

16. Bal AE, Gravekamp C, Hartskeerl RA, et al. Detection of leptospires in urine by PCR for early diagnosis of leptospirosis. J Clin Microbiol 1994;32:1894-8.

17. Cetinkaya B, Ongor H, Muz A, et al. Detection of Brucella species DNA in the stomach content of aborted sheep fetuses by PCR. Vet Rec 1999;144:239-40.

18. Richtzenhain LJ, Cortez A, Heinemann MB, et al. Multiplex PCR for the detection of Brucella spp. and Salmonella abortusovis. DNA from aborted ovine fetuses. Vet Microbiol 2002;87:139-47.

19. Gravekamp C, Van De Kemp H, Franzen M. Detection of seven species of pathogenic leptospires by PCR using two sets of primers. J General Microbiol 1993;139: 1691-700.

20. Navarro E, Escribano J, Fernandez J, Solera J. Comparison of three different PCR methods for detection of Brucella spp in human blood samples. FEMS Immunol Med Microbiol 2002;34:147-51.

21. Tiller RV, Gee JE, Frace MA, et al. Characterization of novel Brucella strains originating from wild native rodent species in North Queensland, Australia. Appl Environ Microbiol 2010;76:5837-45.

22. Vinodh R, Raj GD, Govindarajan R, Thiagarajan V. Detection of Leptospira and Brucella genomes in bovine semen using polymerase chain reaction. Trop Anim Health Prod 2008;40:323-29.

23. Merien F, Amouriaux P, Perolat P, et al. Polymerase chain reaction for detection of Leptospira spp. in clinical samples. J Clin Microbiol 1992;30:2219-24.

24. Leyla G, Kadri G, Umran 0. Comparison of polymerase chain reaction and bacteriological culture for the diagnosis of sheep brucellosis using aborted fetus samples. Vet Microbiol 2003;93:53-61.

25. Salehi M, Pishva E, Salehi R, Rahmani M. 
Isolation of Brucellaabortus using PCRRFLP analysis. Iran J Public Health 2006;35:22-7.

26. Sambrook J, Russell DW. Molecular cloning: a laboratory manual. 3rd ed. New York: Cold Spring Harbor Laboratory Press; 2010. pp. 58-152.

27. Theodoridis D, Bohmer J, Homuth M, Strutzberg-Minder K. Development of a novel ELISA for serodiagnosis of leptospirosis and additional detection of pathogenic Leptospira by polymerase chain reaction for veterinary routine diagnostics. Rev Cubana Med Trop 2005;57:49-50.

28. Leal-Klezevas DJ, Martinez-Vasquez I0, López-Merino A, Martinez-Soriano JP. Single-step PCR for the detection of Brucella ssp. from blood and milk of infected animals. J Clin Microbiol 1995;33:308790.

29. Masri SA, Nguyen PT, Gale P, et al. A polymerase chain reaction assay for the detection of Leptospira spp. in bovine semen. Canad J Vet Res 1997;61:15-20.

30. Maghami GH, Hoshmand-Rad P. Leptospirosis in small mammals of Iran. J Wildlife Dis 1997;13:286-9.

31. Abdollahpour G. A sero epidemiological study on canine and bovine leptospirosis in Tehran province. The 75th Anniversary of Leptospirosis Research Conference, Conference Proceeding, 1990, Matsoyama, Japan. pp: $34-36$

32. Safavieh S, Aghaiypour K. Detection of
Leptospira by PCR. Pajouhesh-vaSazandeghi 2007;74:182-8.

33. Delpy LP, Kaveh M. The occurrence of brucellosis in Iran. The isolation of the causative agent of contagious abortion in cattle. Revenue Fac Méd Vet Teheran 1945;1:21-9.

34. Bokaie S, Sharifi L, Alizadeh $\mathrm{H}$. Epidemiological survey of Brucellosis in human and animal in Birjand, East of Iran. J Anim Vet Adv 2008;7:460-3.

35. Kim S, Lee DS, Suzuki H, Watarai M. Detection of Brucella canis and Leptospira interrogans in canine semen by multiplex nested PCR. J Vet Med Sci 2006;68:615-8.

36. O'leary S, Sheahan M, Sweeney T. Brucella abortus detection by PCR assay in blood, milk and lymph tissue of serologically positive cows. Res Vet Sci 2006;81:170-6.

37. Romero C, Gamazo C, Pardo M, Lopez-Gon I. Specific Detection of Brucella DNA by PCR. J Clin Microbiol 1995;33:615-7.

38. Maghami GR. Study of role of leptospirosis in abortion in Tehran suburb dairy farms. Vet Org Public 1980;20:50-66.

39. Talebkhan M, Ghadakchi H, Vandyousefi J, Nouroozian I. Seroepidemiologic survey of leptospiral infection on Mashhad suburb herds. The 3rd National Congress of Zoonosis in Iran, 1996, Mashhad, Iran. pp 23-25.

40. Firouzi R, Vandyousefi J. Serological survey of leptospirosis in Shiraz suburb dairy herds. Ir J Vet Res 2000;1:118-23.
41. Goli GA. Seroepidemiologic survey of leptospirosis in Karadj herds. 23rd World Buiatrics Congress, Quebec City, Canada. 2002. p 301.

42. Asadpour Y. Serological survey of leptospirosis in cattle in Shaft and Fuman in Gilan province. The 3rd Congress of Veterinary Clinicians in Iran. 1996, Mashhad, Iran. pp. 29-31.

43. Hajikolaei MR, Ghorbanpour Najaf Abadi M, Abdollahpour GR. Serological study of leptospirosis in cattle in Ahvaz. J Faculty Vet Med Univ Tehran 2005;60:7-14.

44. Maghami GR. Reports of parasitology section of Razi Institute. 1967, Hesarak, Karaj, Iran. pp.15-25.

45. Saad A, Phuong T, Pamela S, Howard CJ. A polymerase chain reaction assay for the detection of Leptospira spp. in bovine semen. J Vet Res 1997;61:15-20.

46. Baquero M, López N, Eugenia MM, Trueba G. Evaluation of a polymerase chain reaction for the diagnosis of Leptospirosis in cattle. Open Vet Sci J 2010;4:31-5.

47. Khamesipour F, Doosti A, Taheri H. Molecular detection of Brucella spp. in the semen, testis and blood samples of cattle and sheep. J Pure Appl Microbiol 2013; 7:495-500.

48. Khamesipour F, Doosti A, Omrani E. Molecular study of the prevalence of Leptospira spp. Serovar Hardjo in blood samples of Iranian cattle and sheep. Thai J Vet Med 2014;44:141-6. 